\title{
Utilizing the great blue heron (Ardea herodias) in ecological risk assessments of bioaccumulative contaminants
}

\author{
Rita Marie Seston • Matthew John Zwiernik • Timothy Brian Fredricks • \\ Sarah Jean Coefield • Dustin Lee Tazelaar • David Wayne Hamman • \\ John David Paulson • John Paul Giesy
}

Received: 10 February 2008 / Accepted: 11 September 2008 / Published online: 11 October 2008

(C) The Author(s) 2008. This article is published with open access at Springerlink.com

\begin{abstract}
Selection of an appropriate species is a key element of effective ecological risk assessments (ERA), especially when site-specific field studies are to be employed. Great blue herons $(\mathrm{GBH})$ possess several ideal characteristics of a receptor species for the assessment of bioaccumulative compounds in the environment, such as
\end{abstract}

R. M. Seston ( $\varangle)$ · M. J. Zwiernik · T. B. Fredricks ·

S. J. Coefield · D. L. Tazelaar · J. P. Giesy

Zoology Department, Center for Integrative

Toxicology, National Food Safety and Toxicology

Center, Michigan State University,

East Lansing, MI 48824, USA

e-mail: sestonri@msu.edu

D. W. Hamman

College of Veterinary Medicine,

Center for Comparative Epidemiology,

Michigan State University, East Lansing,

MI 48824, USA

J. D. Paulson

Wildlife Services, USDA-APHIS, Bismarck, ND 58501, USA

J. P. Giesy

Department of Veterinary Biomedical Sciences and Toxicology Centre, University of Saskatchewan, Saskatoon, Saskatchewan S7J 5B3, Canada

J. P. Giesy

Department of Biology and Chemistry,

City University of Hong Kong, Kowloon,

Hong Kong SAR, China ease of study, high potential for exposure, widespread distribution, and territorial foraging behavior. Methodologies for assessing exposure and population health are described herein. As outlined, the collection of GBH eggs, GBH nestling blood, and adult GBH blood allows for the determination of contaminant concentrations in various GBH tissues, a top-down assessment, which can be done in conjunction with predicted dietary exposure, a bottom-up assessment, to support a multiple lines of evidence approach. Additionally, population parameters, such as productivity and survival, can also be measured to elucidate if the contaminant exposure may be causing population level effects. Over the course of two years, three $\mathrm{GBH}$ rookeries were monitored for productivity and nestling exposure. Nests were monitored from blinds and individually accessed at multiple time points to obtain measures of nestling health, band nestlings, and collect eggs and nestling plasma. Multiple nests could frequently be accessed by climbing one tree, resulting in minimal effort to obtain the necessary sample size. Additionally, 51 adult $\mathrm{GBH}$, captured in their foraging areas, were banded, and provided a blood sample. With these samples, a statistical difference in tissue based exposure was identified between the reference and target area. Statistically significant differences were also identified between the upper and lower reaches of the target area, thereby identifying a range of doses geographically which could be 
correlated to specific measurement endpoints. The ability to identify a dose response greatly increases the ability of the dataset to determine causation, a key goal of such studies. Overall, the use of the described methods allowed for the collection of a statistically sufficient and ecologically relevant dataset with reasonable effort and minimal impact on GBH.

Keywords Avian • Bird • Egg • PCDD • PCDF • Plasma $\cdot$ Tittabawassee $\cdot$ Trapping

\section{Introduction}

Selection of appropriate species is a key element to allow effective ecological risk assessments (ERA), especially when site-specific field studies are to be employed. Ideally, representative species used in assessments of bioaccumulative compounds should have an elevated exposure potential, a widespread distribution, and be territorial. Data collected using the selected species should ultimately provide insight into the health of the entire ecosystem of the study site. Piscivorous birds are frequently selected as receptors for evaluating aquatic systems because they can be sensitive to the effects of contaminants and have the potential to accumulate persistent, lipophylic contaminants through trophic-transfer. The great blue heron (Ardea herodias; GBH) possesses several characteristics that make it an appropriate species to use as a receptor in ERAs concerning bioaccumulative contaminants in aquatic environments. Here we describe a multiple lines of evidence approach to elucidating exposure of $\mathrm{GBH}$ to contaminants through the diet and measured concentrations in specific GBH tissues. As a case study of the methodology, we have investigated the exposure of GBH to polychlorinated dibenzofurans (PCDFs) and dibenzo- $p$-dioxins (PCDDs) in the Tittabawassee River basin, Michigan, USA.

The Tittabawassee River study area includes approximately $37 \mathrm{~km}$ of the Tittabawassee River from the upstream boundary of the city limits of Midland, MI to the confluence of the Tittabawassee and Saginaw Rivers downstream of Green Point Island (Fig. 1). Just above the upstream boundary of the study area is a low-head dam. Throughout the study area, the river is free flowing to the confluence with the Saginaw River and eventually Saginaw Bay and Lake Huron. The study area was selected because soils and sediments were found to contain elevated concentrations of PCDFs and PCDDs. Soils and sediments collected from within the study area contained mean PCDF/PCDD concentrations ranging from $1.0 \times 10^{2}$ to $5.4 \times 10^{4} \mathrm{pg} / \mathrm{g} \mathrm{dw}$, which were tento 20-fold greater than those collected upstream in reference areas (Hilscherova et al. 2003). The source of this contamination has been identified as The Dow Chemical Company (USEPA 1986).

PCDFs and PCDDs occur in the environment as mixtures and due to their hydrophobic characteristics and resistance toward metabolism, they have great potential to be accumulated through the food web. The toxicological response of primary concern is mediated through the aryl hydrocarbon receptor (AhR) and effects include carcinogenicity, immunotoxicity, and adverse effects on reproduction, development, and endocrine functions (van den Berg et al. 1998). In particular, AhR-mediated compounds have been shown to decrease hatching success and fledging success in aquatic avian species (Gilbertson 1983; Hoffman et al. 1987; Ludwig et al. 1993; van den Berg et al. 1994).

Desirable, species-specific characteristics of the $\mathrm{GBH}$ led to its inclusion as a receptor species in an ERA concerning PCDFs and PCDDs along the Tittabawassee River and its floodplain. The objective of this paper is to outline a series of methods and the associated effort necessary to effectively employ the GBH as a receptor in an ERA utilizing a multiple line of evidence approach.

\section{Species applicability}

Species-specific attributes need to be considered when selecting a species for use as a receptor. $\mathrm{GBH}$ possess many of the characteristics that are desirable in a receptor species, and as such, are often selected as an ecological receptor of concern in risk assessments. GBH have a broad distribution across geographic regions and habitat 
Fig. 1 Location of great blue heron rookeries (FRE, SNWR, and CAS) and reaches within the Tittabawassee River study area, MI, USA where trapping occurred

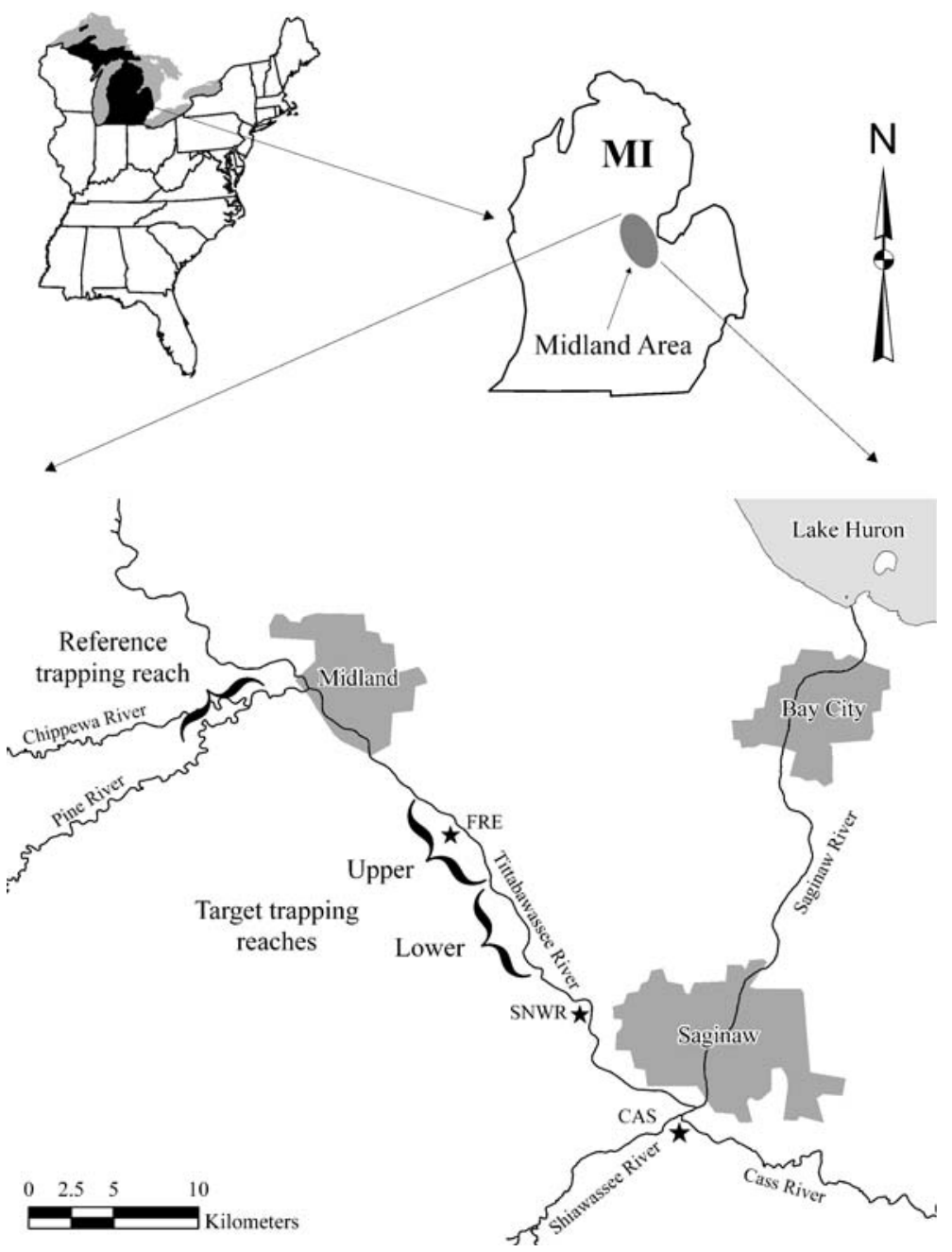

types, residing in freshwater, estuarine, and marine habitats throughout North America (Butler 1992). GBH are a colonially-nesting species, with a rookery containing as many as 1,300 breeding pairs recorded (DesGranges and Desrosiers 2006). With breeding pairs concentrated in one area, the colonies are more conspicuous to researchers than single-nesting species which allows for the assessment of population health rather than the outcome of a few nesting pairs. There are many closely related species for which GBH could serve as a surrogate species or that could be studied utilizing the described methods. Additionally, GBH are a charismatic species that is widely recognized by the general public, which would have an interest in preserving this species.
As a long-lived territorial species at the top of the aquatic food web, GBH have the potential to bioaccumulate local contaminants over a long period of time (Custer et al. 1991). Band recoveries have shown GBH may live to be at least 20 years old (Bayer 1981). GBH are year-round residents in areas of its range where foraging remains available during winter months, particularly in coastal areas (Butler 1997). The territorial nature of $\mathrm{GBH}$ leads to the active defense of distinct, identifiable foraging areas local to the breeding colony (Peifer 1979; Marion 1989), thus GBH exposure may have a greater spatial resolution as compared to other more opportunistically feeding piscivorous birds. Previous studies have detected local organochlorine contaminants in the 
tissues of GBH (Custer et al. 1997; Thomas and Anthony 1999; Elliott et al. 2001; Champoux et al. 2002; Harris et al. 2003; Straub et al. 2007).

\section{Methods}

Nest monitoring and fresh egg sampling

Great blue heron nests were monitored during the nesting season, which begins in mid- to late March and runs through mid-July, of 2006 and 2007. Colonies were visited several times over the breeding season to monitor reproductive success. Visits were coincident with estimated mean nesting, hatching, chick rearing, and fledgling periods and separated by a minimum of 1 week to minimize disturbance to breeding pairs. Calculation of events was based on a 2-week courtship/nesting period, 4-week incubation period, and a minimum of 8 weeks from hatching to fledging (Harris et al. 2003). For the second year of nest monitoring (2007), a helicopter with a stabilized zoom lens was employed to determine the number of eggs in each nest. Surveys were conducted from an altitude of $100 \mathrm{~m}$ to minimize disturbance. By flying at this altitude, incubating GBH were not flushed from nests and were not visually disturbed by the helicopter. An entire rookery could be surveyed in approximately $15 \mathrm{~min}$, capturing both video footage and still images. The contents of the nest could only be determined and counted for nests which the adults were not incubating at the time of survey, but the number of active nests in the rookery could be determined. Hatching date was estimated by the presence of eggshells on the ground beneath nests and observing the act of herons presenting sticks to their mates (Moul et al. 2001), along with hearing the nestlings calling in nests. Estimates of hatching and fledging success were then made when chicks were estimated to be 4 and 8 weeks of age, respectively. At 4 weeks of age the nestlings could be seen and counted in the nest and at 8 wk of age nestlings would perch on branches proximal to the nest. Observations were conducted from semi-permanent blinds erected in the nesting colony. A final visit to the colony was made each year once the leaves had fallen from the trees to make a count of the total number of nests.

Nests were located in Eastern cottonwood (Populus deltoides), silver maple (Acer saccharinum), or white ash (Fraxinus americana) trees at heights ranging between 15 and $25 \mathrm{~m}$. Viable and nonviable eggs were collected from accessible nests in each nesting colony. Nest trees were selected based on the safety of access and the potential to reach multiple nests. Tree climbers accessed nests using tree-climbing spikes. Eggs were collected with a nylon stocking cup attached to the end of an extendable pole from the nesting tree or a neighboring tree that was in near enough proximity (Hines and Custer 1995). A maximum of one viable egg was collected at random from each accessed nest that contained $\geq 2$ eggs. In addition to viable eggs, all eggs which failed to hatch were collected for analysis of developmental stage and contaminant content. Eggs were weighed and measured, and then carefully transported to the laboratory in a crush-proof, water-proof container and kept at $4{ }^{\circ} \mathrm{C}$ until processing.

\section{Capture and handling of nestling GBH}

Blood was collected from nestlings when they were approximately four to 5-week old based on methods previously described in (Henny and Meeker 1981). At this age, nestlings were still limited to movement within the nest yet had sufficient mass to provide an adequate volume of plasma for residue analyses (McAloney 1973). Some of the nestlings handled were older than the target age and proved to be more difficult to retrieve from and replace into the nest. An extendable pole with a retractable wire hoop was used to reach nestlings (Ketch-All Co., 4149 Santa Fe Rd. 2, San Luis Obispo, CA 93401). Individual nestlings were placed in a cloth bag and lowered to the ground from the nest. A 7-10 $\mathrm{cm}$ piece of closed-cell polyethylene foam tubing $(7 \mathrm{~cm}$ OD $\times$ $3 \mathrm{~cm}$ ID Swim Noodle) was used to shield the potentially hazardous beak. The bill of the $\mathrm{GBH}$ was inserted into the tubing and a sock was pulled over both the tubing and the bird's head to cover the eyes of the captured bird and to keep the tubing in place. This combination reduced the chance of injury to personnel by covering the sharp 
beak, minimized visual stimulation resulting in a calming of the bird, while allowing it to breathe freely. Individuals were placed in the cloth bag to determine their body weight by a spring scale (Model 42500, Pesola AG, Switzerland). Lengths of exposed culmen and tarsus and masses were determined for each individual nestling. The age of each nestling was estimated using an equation relating age and culmen length from Quinney (1982). Individuals were fitted with USFWS bands on the tarsus and colored leg bands on the tibia (Simpson and Kelsall 1978). Color leg bands were made from $49 \mathrm{~mm}$ high $\times 66 \mathrm{~mm}$ wide pieces of 2-ply plastic (1/16" Gravoglas 2-plex, matte-finish; Gravograph-New Hermes, Inc., Duluth, GA) wrapped around a wooden dowel to have a diameter equal to that of the 7B USFWS leg bands $(14 \mathrm{~mm})$, as described in Hayes and Barzen (2006).

Salvaged nestlings were collected opportunistically following weather events or as a result of siblicide. Nestlings were examined for any gross external or internal abnormalities including liver, kidney, spleen, intestine, and gonad histology. Nestling stomach contents were analyzed to the lowest taxonomic identification possible to aid in the elucidation of a site-specific dietary composition. Contaminant concentrations were determined for liver, adipose, and skeletal muscle tissues of each individual nestling.

\section{Capture and handling of adult GBH}

Adult GBH were captured using modified foot hold traps set around feeding stations in predetermined GBH foraging areas. Foot hold traps were modified in a manner similar to that described by King et al. (1998). Briefly, the factory coil springs of Victor 3 Softcatch traps (Oneida Victor, Inc., Ltd., Euclid, OH) were replaced with weaker Victor 1.25 Softcatch coil springs. This modification lessened the initial impact of the padded jaws but still kept enough tension to hold the trapped bird's leg in place. The chain supplied with the trap was replaced with either a $15 \mathrm{~cm}$ or $30 \mathrm{~cm}$ length of elastic shock-cord attached with swivels on both ends to allow freedom of movement and minimization of injury to captured birds. Feeding stations were established in areas of the river with substratum ranging from sandy-silt to small pebbles, water depth of approximately 15 to $46 \mathrm{~cm}$, and where GBH were observed foraging or tracks were present. The stations were placed in areas with little current to reduce stress on the bait fish, and free of debris to reduce the chance of injury to captured GBH. The feeding stations were opentop $46 \mathrm{~cm} \mathrm{~L} \times 30 \mathrm{~cm} \mathrm{~W} \times 41 \mathrm{~cm} \mathrm{H}$ cages constructed of $1.25 \mathrm{~cm}$ galvanized hardware cloth on a frame of $0.60 \mathrm{~cm}$ hot-roll rod. Each station was fitted with $1.25 \mathrm{~cm}$ urethane pipe insulation along each of the long edges and anchored in the river by a $1.25 \mathrm{~m}$ piece of smooth rebar passed through two hoops on one corner of the cage. This design allowed the stations to float while remaining anchored, accommodating the fluctuating water levels of the river, and preventing the loss of the bait fish. The top-edge of the cage was fitted with $0.95 \mathrm{~cm}$ Tygon ${ }^{\circledR}$ tubing to protect the trapped bird from any potentially sharp edges. The feeding stations were stocked with forage fish collected from the immediate area. Fish were collected by seine net or backpack electro-fisher (Smith-Root LR-24, Smith-Root Inc., Vancouver, WA). Once GBHs were regularly foraging from the feeding station, approximately 40 modified traps were placed in a staggered configuration around the feeding station. The cord of each trap was outfitted with a clip, which attached the traps to a galvanized steel cord secured with stakes around the station. Loaded traps were set by placing firmly into the sediment to stabilize the trap, taking care not to bury the springs, pan, or pin. Feeding stations were monitored by personnel in a nearby blind (Doghouse blind, Ameristep Inc., Clio, MI) anytime the traps were set. Optimal blind location was on the bank opposite the feeding station, if the river could easily be crossed. This allowed for the largest field of view and minimized potential disturbance of GBH approaching the feeding station. If this was not possible, blinds were placed at least $30 \mathrm{~m}$ away from the feeding station in as much cover that still allowed a clear view of the feeding station and shoreline. Trapping along this river system was limited to summer months, when the river's water levels were lower and more stable. Captured birds were approached with extreme caution as great blue herons are equipped with strong, sharp beaks and are known to be 
aggressive (Butler 1997). Personnel handling the birds were outfitted with appropriate protective gear including helmets fitted with face shields and thick woven clothing. Captured adult GBH were hooded in the same manner as nestlings.

Once safely immobilized, individuals were color marked using numbered color leg bands placed on the tibia. Color leg bands used on the adults were identical to those used on nestlings with the addition of unique numerical codes of $14 \mathrm{~mm}$ numbers spaced $11 \mathrm{~mm}$ apart in three vertical rows to increase visibility on the banded bird. Color marking was done to enable identification of captured adults from a distance. Measurements of other physical attributes such as the length of the exposed culmen, wing chord, and tarsus and mass were also recorded. Each individual was also fitted with a US Fish \& Wildlife Service band on the tarsus.

\section{Blood plasma sampling}

Blood from nestling and adult GBH was drawn from the brachialis vein using needles affixed to sterile syringes pre-rinsed with sodium heparin solution. 22-gauge needles (Becton Dickinson, Franklin Lakes, NJ) were used for nestlings while smaller 25-gauge needles were used for adults due to smaller vein size. To determine the maximum volume of blood that could be collected, the following set of equations were utilized; 7\% body weight $=$ total blood volume, $10 \%$ total blood volume $=$ acceptable sample volume. Blood collection was most effectively performed with three people, one to hold the head, legs, and body of the GBH still, one keeping the wing outstretched and steady, and one to perform the blood draw. The blood sample was then transferred to a heparinized Vacutainer ${ }^{\mathrm{TM}}$ (Becton Dickinson, Franklin Lakes, NJ) for transport back to the field laboratory. Each Vacutainer ${ }^{\mathrm{TM}}$ was labeled with the band number, trapping station ID, GPS coordinates of trapping station, date, and collector's initials. Whole blood samples were centrifuged and the plasma (supernatant) was decanted. Both plasma and packed cell volume were stored at $-20^{\circ} \mathrm{C}$ until analysis. Red blood cells were saved for future sexing of individuals.
Collection of prey items

Site-specific GBH dietary items, including forage fish, amphibians, and crayfish, were collected and analyzed for contaminant concentrations (Alexander 1977). Collection of the dietary items occurred at six sampling locations, two in the reference area and six approximately equally spaced throughout the $27 \mathrm{~km}$ target area. The sampling scheme maximized information on dietary exposure including geographically associated contaminant variability and trends.

\section{Sample processing and analytical techniques}

Collected eggs were opened around the girth with a chemically cleaned scalpel blade and assessed for stage of development and the presence of any abnormalities. Contents were then homogenized in a chemically cleaned Omnimixer, lyophilized, and stored in clean jars until analysis (I-CHEM brand, Rockwood, TN). Tissues collected from salvaged nestlings were also homogenized using a chemically cleaned Omnimixer. All samples were analyzed for concentrations of the seventeen 2,3,7,8-substituted PCDF/D congeners, in addition to a subset of egg and tissue samples also being analyzed for PCB and DDXs. Analyses were conducted in accordance with EPA Method 8290 with minor modifications (USEPA 1998). In summary, biotic matrices were homogenized with anhydrous sodium sulfate and Soxhlet extracted for $16 \mathrm{hr}$ using $400 \mathrm{ml}$ toluene. The extraction solvent was transferred to hexane and the extract was concentrated to $10 \mathrm{ml}$. Before extraction known amounts of ${ }^{13} \mathrm{C}$ labeled PCDF/Ds were added as internal standards. Extracts were initially purified by treatment with concentrated sulfuric acid. The extract was then passed through a multilayer silica gel column containing silica gel and sulfuric acid silica gel and eluted with $150 \mathrm{ml}$ of $10 \%$ dichloromethane in hexane. The extract is then passed through a carbon column packed with $1 \mathrm{~g}$ of activated carbon-impregnated silica gel. The first fraction, eluted with $100 \mathrm{ml}$ hexane, was kept for PCB analysis. The second fraction, eluted with $200 \mathrm{ml}$ of toluene, contained the 2,3,7,8-substituted 
PCDF/Ds. PCDF/Ds were analyzed using HRGCHRMS, a Hewlett-Packard 6890 GC (Agilent Technologies, Wilmington, DE) connected to a MicroMass high resolution mass spectrometer (Waters Corporation, Milford, MA). PCDF and PCDD congeners were separated on a DB-5 capillary column (Agilent Technologies, Wilmington, DE) coated at $0.25 \mu \mathrm{m}(60 \mathrm{~m} \times 0.25 \mathrm{~mm}$ i.d. $)$. Generally, the mass spectrometer was operated at an EI energy of $60 \mathrm{eV}$ and an ion current of $600 \mu \mathrm{A}$. PCDF/D congeners were monitored by single ion monitoring (SIM) at the two most intensive ions at the molecular ion cluster. Concentrations of certain PCDF/D congeners, particularly TCDD and TCDF congeners were confirmed by using a DB-17 $(60 \mathrm{~m} \times 0.25 \mathrm{~mm}$ i.d., $0.25 \mu \mathrm{m}$ film thickness) column (Agilent Technologies, Wilmington, DE). Chemical analyses included pertinent quality assurance practices, including surrogate spikes, blanks, and duplicates. Soxhlet extractions and chemical analyses were conducted at AsureQuality Limited, Lower Hutt, New Zealand.

\section{Results}

\section{Rookery}

Three active GBH rookeries were located within the study area. The Freeland rookery (FRE) was established in 2001, and contained 44 nests in 2006 and 46 nests in 2007. The Shiawassee National Wildlife Refuge rookery (SNWR), established in 1999, contained 161 nests in 2006, but nest occupancy has drastically decreased after the recent establishment of predatory avian species, including bald eagles (Haliaeetus leucocephalus), great horned owls (Bubo virginianus), and redtailed hawks (Buteo jamaicensis), within the rookery. A second rookery located on the Shiawassee National Wildlife Refuge near the confluence of the Cass and Shiawassee Rivers (CAS), contains approximately 35 nests. CAS was established in 1989 but has only been occupied periodically. No rookeries were located within the reference area. From each rookery, a target sample size of eight fresh eggs was collected, each from separate nests
Table 1 Description of sampling effort and summary of great blue heron tissues collected through utilizing described methodologies

\begin{tabular}{|c|c|c|c|c|c|}
\hline \multirow[t]{2}{*}{ Year } & \multirow{2}{*}{$\begin{array}{l}\text { Reference } \\
\text { Adult } \\
\text { plasma }\end{array}$} & \multicolumn{4}{|l|}{ Target } \\
\hline & & $\begin{array}{l}\text { Adult } \\
\text { plasma }\end{array}$ & $\begin{array}{l}\text { Egg } \\
\text { collection }^{a}\end{array}$ & $\begin{array}{l}\text { Nestling } \\
\text { plasma }^{\mathrm{a}}\end{array}$ & $\begin{array}{l}\text { Nestling } \\
\text { tissue }^{\mathrm{a}}\end{array}$ \\
\hline 2005 & 5 & 15 & & & \\
\hline 2006 & 10 & 9 & $6(6)$ & $13(8)$ & $9(4)$ \\
\hline 2007 & & 12 & 19 (18) & $29(15)$ & $2(2)$ \\
\hline Total & 15 & 36 & $25(24)$ & $42(23)$ & $11(6)$ \\
\hline
\end{tabular}

Note that there was no rookery located in the reference area to sample. Necessary adult plasma sample size in reference area obtained after 2006 field season

${ }^{a}$ Values in parentheses indicate the total number of nests samples collected from $(n)$

in the rookery. This collection of tissue from 24 different nests required climbing only seven different trees, with up to four nests being accessible in one tree. Collection of fresh eggs often involved incubation disturbance within the rookery so it was only done when temperatures were greater than $15^{\circ} \mathrm{C}$. Time required for egg sampling was on average $0.66 \mathrm{~h} / \mathrm{egg}$ or $2.25 \mathrm{~h} /$ tree, with sampling efficiency increasing as climbers became more experienced with the technique. Nestling banding and blood plasma collection occurred at all rookeries. At FRE, 12 nests were accessed for nestling banding and blood plasma collection, for a total of 20 nestling blood plasma samples. Four nests at SNWR produced samples of blood from eight nestlings. Samples of blood were obtained from 14 individuals from seven nests at CAS. Time required for nestling blood plasma collection averaged $0.90 \mathrm{~h} / \mathrm{sample}$ or $1.63 \mathrm{~h} /$ nest. Two salvaged nestlings were collected from one nest at FRE, seven salvaged nestlings were collected from three separate nests at SNWR, and two salvaged nestlings from two separate nests at CAS. A summary of collected tissues is outlined in Table 1.

\section{Adult trapping}

Twelve GBH trapping stations were established, three located in the reference area and nine in the target study area. By employing the described methods, there were 62 capture events, which 


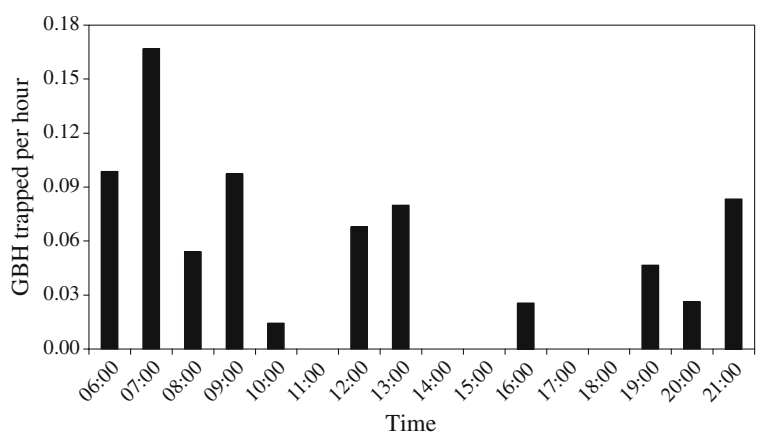

Fig. 2 Number of great blue herons trapped in the Tittabawassee River study area between 2005 and 2007 using the bait station and foot-hold trapping method. Number of $\mathrm{GBH}$ normalized to the number of trapping hours

included the capture of $51 \mathrm{GBH}$, nine recaptures, and two escapes. All GBH recaptures occurred at their original trapping station, with one exception where the trapping stations were less than $500 \mathrm{~m}$ apart. Once recaptures occurred at any given feeding station, that station was moved to a new foraging territory to target new GBH. One GBH was recaptured two consecutive years at the same feeding station. Over the course of a field season as many as five individuals were trapped at one feeding station. Of the $51 \mathrm{GBH}$ captured, 15 were in the reference area and 36 in the target area (Table 1). On average, a GBH adult plasma sample was obtained for every $15.26 \mathrm{~h}$ of active trapping, which was conducted by a two-person team. Including recaptures and escapes, on average one GBH was captured for every $12.56 \mathrm{~h}$ of active trapping. These figures do not include time spent maintaining the stock of fish in the feeding stations. Normalized to the number of trapping hours, the most successful time of day to conduct trapping was from 0600 to 1000 hours (Fig. 2), with a trapping success rate of approximately $0.12 \mathrm{GBH} / \mathrm{h}$. Average time from capture to release of $\mathrm{GBH}$ was $60 \mathrm{~min}$. Injuries associated with adult trapping and handling were low and no injuries were sustained to adult GBH that would be expected to impact survival. A damaged or torn leg scale was noted for eight of the 62 birds trapped and a broken phalange (non-hallux) was noted for a single bird.
Table 2 Total TEQ $(\mathrm{pg} / \mathrm{ml})$ in adult GBH blood plasma from Tittabawassee River study area collected during 2005 field season

\begin{tabular}{lcllc}
\hline & Mean & St. Dev. & Min & Max \\
\hline Reference $(n=5)$ & 1.8 & 0.75 & 1.2 & 3.0 \\
Upper target $(n=10)$ & 8.4 & 5.5 & 2.2 & 17 \\
Lower target $(n=5)$ & 12 & 5.5 & 8.5 & 20 \\
\hline
\end{tabular}

\section{Sampling effectivity}

Power analyses were conducted using total TEQs $(\mathrm{pg} / \mathrm{ml})$ in the blood plasma of sampled adults from the 2005 field season (Table 2). These analyses revealed that a significant difference could be discerned between the reference and target area with a type $\mathrm{I}(\alpha)$ error rate of 0.05 and a type II $(\beta)$ error rate of 0.20 with as few as four samples from each area. Additionally, the target area could be divided into an upper and lower reach with significant differences discernable at the same errors rates with 14 samples collected from each area. Analytical results from the other matrices were not available to conduct site-specific power analyses.

\section{Discussion}

Selection of a receptor species is a key element to an effective ERA, especially when site-specific field studies are to be employed. As a long-lived species near the top of the aquatic food web, $\mathrm{GBH}$ have the potential to be highly exposed to contaminants for many years. Residing in freshwater, estuarine, and marine habitats throughout North America, GBH have the potential to be utilized in ERAs in many different locales. The territorial foraging behavior of GBH leads to the active defense of distinct and identifiable foraging areas. Additionally, GBH have many closely related species which share some of these desirable attributes and could be studied using these same methods. All of these characteristics make the $\mathrm{GBH}$ a model receptor species for the assessment of bioaccumulative compounds in an aquatic food web, and led to their inclusion in the ERA conducted for the Tittabawassee River floodplain. 
Although all of the aforementioned characteristics are important to have in a receptor species, they become irrelevant if the species is too difficult to study and acquire the necessary samples. Since $\mathrm{GBH}$ are a colonial nesting species, the discovery of one rookery results in the location of tens to hundreds of breeding pairs. This allows a multitude of nests to be monitored simultaneously for reproductive success and nestling dietary composition, and an assessment of population health rather than the health of a few individuals. In the studied rookeries, multiple nests could often be sampled for eggs or nestling handling by climbing one tree, reducing the effort needed to obtain the necessary sample size. In addition to comparing population health parameters from study areas to appropriate reference areas, comparisons may also be made with other studies which report productivity that are available in the literature (Pratt 1970; Thomas and Anthony 1999; Harris et al. 2003; Witt 2006). Conversely, GBH characteristics of nesting at great heights in small diameter and sometimes dead trees can make both groundbased observations and physical nest access challenging. For the rookeries monitored here, ground blind observations were supplemented with observations from rotary wing aircraft to assess clutch size. However, access to nests was limited to trees that were safely climbable. Date, time of flight, and nonrandom limitations to physical nest access may add bias to measurements and should be noted for within and across study comparisons.

The collection of nestling blood plasma and eggs from the same nest allows for the possible derivation of a plasma-to-egg ratio, which would eliminate the need for destructive egg sampling. $\mathrm{GBH}$ are a migratory species, so it is possible that contaminants transferred to the egg from the female were accumulated elsewhere (Henny and Blus 1986); however, eggs collected from rookeries in the study area exhibited low variation in total TEQs and congener profiles within and among rookeries, suggesting this was not an important factor at this site. Nestlings are considered to be more representative of local contamination as they are confined to the nest and rely on the food brought to them by adults (Olsson et al. 2000; Neigh et al. 2006). Studies tracking adult GBH from rookeries to foraging areas have determined that adult GBH forage a mean distance between $3.1 \mathrm{~km}$ and $6.5 \mathrm{~km}$ from breeding colonies, although a distance as great as $34.1 \mathrm{~km}$ has been recorded (Thompson 1978; Peifer 1979; Dowd and Flake 1985). To further characterize site-specific dietary exposure, the habit of $\mathrm{GBH}$ nestlings to regurgitate their stomach contents when under duress can be exploited by collecting the regurgitant to determine dietary composition and contaminant concentrations. Additionally, the described methods facilitate the collection of plasma samples from multiple nestlings within a single nest to determine intra-brood variation. This dataset combined with eggs from the same nest can generate plasma-to-egg ratios, which can be a useful tool; however, they must only be used when both eggs and plasma are representative of local contamination. These ratios are especially desirable when dealing with endangered or threatened species when avoiding any destructive sampling is of great importance (Strause et al. 2007).

The territorial foraging of GBH facilitates the establishment of feeding stations in multiple foraging territories in the area of interest to capture different individuals with a low rate of recapture. Throughout the three field seasons during which trapping of adult GBH was performed, the feeding station and foot-hold trap method proved to be very effective, as demonstrated by the fifty different individuals that were captured, banded, and provided a blood plasma sample. As many as five individuals were trapped at one feeding station over the course of one field season. Along a river system in South Dakota, Dowd and Flake (1985) determined that radio-tagged GBH would return to the same general areas of the river, but other $\mathrm{GBH}$ were also observed using the same areas. Additionally, fledgling GBH did not seem to display aggressive territorialism over foraging areas and were often seen foraging in flocks. In the closely related grey heron (Ardea cinerea), other foragers would visit actively defended territories in the absence of the territory owner (Marion 1989). One individual GBH was recaptured two consecutive years at the same feeding station, which suggests territories may be maintained over multiple years. No banded birds were recaptured 
at feeding stations other than where they were initially trapped, except where the feeding stations were less than $500 \mathrm{~m}$ apart, again reinforcing the territoriality of $\mathrm{GBH}$ foraging. Additionally, the recapture of $\mathrm{GBH}$, sometimes multiple times in the same day, suggests that either this trapping method was not traumatic or injurious as compared to the desire for easy prey. The level of effort involved in adult trapping could potentially be lessened by focusing trapping effort during certain times of the day, during the nesting season, or in areas of group foraging. When normalized to the number of trapping hours, the period from 0600 to 1000 hours had the greatest trapping success rate, at approximately $0.12 \mathrm{GBH} /$ hour. In the present study, trapping was focused in solitary feeding areas in an attempt to quantify site fidelity and to minimize the effects of foraging disturbance on additional birds.

The temporal consistency of both data access and exposure potential for $\mathrm{GBH}$ adds potential flexibility in study design and sampling efforts. For instance, we used power analysis of first year data to identify spatially explicit boundaries for which statistically significant differences could potentially be identified at a reasonable level of effort. This adds value to the study by providing for a real-time cost benefit analysis and the most efficient allocation of resources.

The methodologies employed in this study provided multiple ways of estimating exposure, including dietary exposure and tissue-based exposure assessments. Although an exact site-specific dietary composition was not calculated, a combination of literature-based diets and observations of site-specific GBH foraging led to the collection of forage fish, crayfish, and amphibians as the primary diet components. Analysis of these items allowed for the calculation of estimated average daily intake and resulting HQs for dietary exposure. Determination of concentrations of PCDDs/Fs in egg, nestling tissues, and nestling and adult plasma allowed for the determination of HQs based on tissue concentrations. Comparisons can then be made between the HQs derived from the varying approaches to determine the accuracy of predicting exposure through the diet and the importance of collecting receptor tissues.
Acknowledgements The authors would like to thank all staff and students of the Michigan State UniversityAquatic Toxicology Laboratory field crew; namely Michael W. Nadeau, Will R. Folland and Stephanie C. Plautz for their tree-climbing abilities, along with Emily M. Koppel, Jeremy N. Moore, Bretton J. Joldersma, Megan L. Barker, Joost van Dam, Lori E. Williams, and Casey L. Bartrem. We gratefully acknowledge Mikes Fales for his design and fabrication of specialized equipment which was pivotal to the success of this research. Additionally, we would like to recognize Patrick W. Bradley, Michael J. Kramer, and Nozomi Ikeda for their assistance in the laboratory, James Dastyck and Steven Kahl of the US Fish and Wildlife Service-Shiawassee National Wildlife Refuge, for their assistance and access to the refuge, the Saginaw County Parks and Recreation Commission for access to Imerman Park, and the Tittabawassee Township Park Rangers for access to Tittabawassee Township Park and Freeland Festival Park. We would also like to acknowledge the more than 50 cooperating landowners throughout the study area who have granted us access to their property, making our research possible. Funding was provided through an unrestricted grant from The Dow Chemical Company, Midland, Michigan to J.P. Giesy and M. J. Zwiernik of Michigan State University.

Animal use All aspects of the study that involved the use of animals were conducted in the most humane means possible. To achieve that objective, all aspects of the study were performed following standard operation procedures (GBH adult handling 03/05-036-00; GBH nest monitoring 05/07-066-00; Field studies in support of TR ERA 03/04042-00; Protocol for fish sampling 03/04-043-00) approved by Michigan State University's All University Committee on Animal Use and Care (AUCAUC). All of the necessary state and federal approvals and permits (Michigan Department of Natural Resources Scientific Collection Permit SC1254/SC permit for fish (Zwiernik)/SC permit for amphibians (Zwiernik) and USFWS Migratory Bird Scientific Collection Permit MB1000062-0) are on file at MSU-ATL.

Open Access This article is distributed under the terms of the Creative Commons Attribution Noncommercial License which permits any noncommercial use, distribution, and reproduction in any medium, provided the original author(s) and source are credited.

\section{References}

Alexander, G. R. (1977). Food of vertebrate predators on trout waters in north central lower Michigan. Michigan Academician, 10, 181-195. 
Bayer, R. D. (1981). Regional variation of great blue heron longevity. Journal of Field Ornithology, 52, 210-213.

Butler, R. W. (1992). Great blue heron. In A. Poole, P. Stettenheim, \& F. Gill (Eds.), The birds of North America, No. 25. Philadelphia: The Academy of Natural Sciences.

Butler, R. W. (1997). The great blue heron: A natural history and ecology of a seashore sentinel. Vancouver, BC: UBC Press

Champoux, L., Rodrigue, J., DesGranges, J., Trudeau, S., Hontela, A., Boily, M., et al. (2002). Assessment of contamination and biomarker response in two species of herons on the St. Lawerence River. Environmental Monitoring and Assessment, 79, 193-215. doi:10.1023/ A:1020289425542.

Custer, T. W., Hines, R. W., Melancon, M. J., Hoffman, D. J., Wickliffe, J. K., Bickham, J. W., et al. (1997). Contaminant concentrations and biomarker response in great blue heron eggs from 10 colonies on the upper Mississippi River, USA. Environmental Toxicology and Chemistry, 16, 260-271. doi:10.1897/1551-5028 (1997)016<0260:CCABRI>2.3.CO;2.

Custer, T. W., Rattner, B. A., Ohlendorf, H. F., \& Melancon, M. J. (1991). Herons and egrets as proposed indicators of estuarine contamination in the United States. Acta XX Congressus Internationalis Ornithologici, 20, 2474-2479.

DesGranges, J., \& Desrosiers, A. (2006). Breeding distribution and population trends of the great blue heron in Quebec, 1977-2001. Canadian Wildlife Service (CWS) Occasional Paper No. 113. Ottawa, Ontario, Canada: Environment Canada.

Dowd, E. M., \& Flake, L. D. (1985). Foraging habitats and movements of nesting great blue herons in a prairie river ecosystem, South Dakota. Journal of Field Ornithology, 56, 379-387.

Elliott, J. E., Harris, M. L., Wilson, L. K., Whitehead, P. E., \& Norstrom, R. J. (2001). Monitoring temporal and spatial trends in polychlorinated dibenzo- $p$ dioxins (PCDDs) and dibenzofurans (PCDFs) in eggs of great blue heron (Ardea herodias) on the coast of British Columbia, Canada, 1983-1998. Ambio, 30, 416428. doi:10.1639/0044-7447(2001)030[0416:MTASTI] 2.0.CO;2.

Gilbertson, M. (1983). Etiology of chick edema disease in herring gulls in the lower Great Lakes. Chemosphere, 12, 357-370. doi:10.1016/0045-6535(83)90110-8.

Harris, M. L., Elliott, J. E., Butler, R. W., \& Wilson, L. K. (2003). Reproductive success and chlorinated hydrocarbon contamination of resident great blue herons (Ardea herodias) from coastal British Columbia, Canada, 1977 to 2000. Environmental Pollution, 121, 207-227. doi:10.1016/S0269-7491(02)00220-8.

Hayes, M. A., \& Barzen, J. A. (2006). Dynamics of breeding and non-breeding sandhill cranes in southcentral Wisconsin. The Passenger Pigeon, 68, 345-352.

Henny, C. J., \& Blus, L. J. (1986). Radiotelemetry locates wintering grounds of DDE-contaminated black- crowned night-herons. Wildlife Society Bulletin, 14, 236-241.

Henny, C. J., \& Meeker, D. L. (1981). An evaluation of blood plasma for monitoring DDE in birds of prey. Environmental Pollution Series A, 25, 291-304.

Hines, R. K., \& Custer, T. W. (1995). Evaluation of extendable pole-net to collect heron eggs in the canopy of tall trees. Colonial Waterbirds, 18, 120-122. doi:10.2307/ 1521409.

Hilscherova, K., Kannan, K., Nakata, H., Hanari, N., Yamashita, N., Bradley, P. W., et al. (2003). Polychlorinated dibenzo- $p$-dioxin and dibenzofuran concentration profiles in sediments and flood-plain soils of the Tittabawassee River, Michigan. Environmental Science \& Technology, 37, 468-474. doi:10.1021/ es020920c.

Hoffman, D. J., Rattner, B. A., Sileo, L., Docherty, D. E., \& Kubiak, T. J. (1987). Embryotoxicity, teratogenicity, and aryl hydrocarbon hydroxylase activity in Forster's terns on Green Bay, Lake Michigan. Environmental Research, 42, 176-184. doi:10.1016/ S0013-9351(87)80019-1.

King, D. T., Paulson, J. D., Leblanc, D. J., \& Bruce, K. (1998). Two capture techniques for American white pelicans and great blue herons. Colonial Waterbirds, 21, 258-260. doi:10.2307/1521917.

Ludwig, J. P., Auman, H. J., Kurita, H., Ludwig, M. E., Campbell, L. M., Giesy, J. P., et al. (1993). Caspian tern reproduction in the Saginaw Bay ecosystem following a 100-year flood event. Journal of Great Lakes Research, 19, 96-108.

Marion, L. (1989). Territorial feeding and colonial breeding are not mutually exclusive: The case of the grey heron (Ardea cinerea). Journal of Animal Ecology, 58, 693-710. doi:10.2307/4857.

McAloney, K. (1973). The breeding biology of the great blue heron on Tobacco Island, Nova Scotia. Canadian Field Naturalist, 87, 137-140.

Moul, I. E., Vennesland, R. G., Harris, M. L., \& Butler, R. W.(2001). Standardizing and interpreting nesting records for great blue herons in British Columbia. Canadian Wildlife Service (CWS) Progress Note No. 217. CWS, Pacific and Yukon Region, Vancouver, BC, Canada. Retrieved from http://www.cws-scf.ec.gc. ca/publications/notes/217/cont_e.pdf.

Neigh, A. M., Zwiernik, M. J., Bradley, P. W., Kay, D. P., Park, C. S., Jones, P. D., et al. (2006). Tree swallow (Tachycineta bicolor) exposure to polychlorinated biphenyls at the Kalamazoo River Superfund Site, MI, USA. Environmental Toxicology and Chemistry, 25, 428-437. doi:10.1897/04-493R.1.

Olsson, A., Ceder, K., Bergman, A., \& Helander, B. (2000). Nestling blood of the white-tailed sea eagle (Haliaeetus albicilla) as an indicator of territorial exposure to organohalogen compounds - an evaluation. Environmental Science \& Technology, 34, 2733-2740. doi:10.1021/es991426k.

Peifer, R. W. (1979). Great blue herons foraging for small mammals. The Wilson Bulletin, 91, 630-631. 
Pratt, H. M. (1970). Breeding biology of great blue herons and common egrets in central California. The Condor, 72, 407-416. doi:10.2307/1366387.

Quinney, T. E. (1982). Growth, diet, and mortality of nestling great blue herons. The Wilson Bulletin, 94, 571-577.

Simpson, K., \& Kelsall, J. P. (1978). Capture and banding of adult great blue herons at Pender Harbour, British Columbia. Proceedings Colonial Waterbird Group, 3, 71-78.

Straub, C. L., Maul, J. D., Halbrook, R. S., Spears, B., \& Lydy, M. J. (2007). Trophic transfer of polychlorinated biphenyls in great blue heron (Ardea herodias) at Crab Orchard National Wildlife Refuge, Illinois, United States. Archives of Environmental Contamination and Toxicology, 52, 572-579. doi: 10.1007/s00244-006-0200-6.

Strause, K. D., Zwiernik, M. J., Im, S. H., Newsted, J. L., Kay, D. P., Bradley, P. W., et al. (2007). Plasma to egg conversion factor for evaluating polychlorinated biphenyl and DDT exposures in great horned owls and bald eagles. Environmental Toxicology and Chemistry, 26, 1399-1409. doi:10.1897/06-383R.1.

Thomas, C. M., \& Anthony, R. G. (1999). Environmental contaminants in the great blue herons (Ardea herodias) from the Lower Columbia and Willamette Rivers, Oregon and Washington, USA. Environmental Toxicology and Chemistry, 18, 2804-2816. doi:10.1897/1551-5028(1999)018<2804:ECIGBH>2.3. $\mathrm{CO} ; 2$.

Thompson, D. H. (1978). Feeding areas of great blue herons and great egrets nesting within the floodplain of the upper Mississippi River. Proceedings of the Colonial Waterbird Group, 2, 202-213. doi:10.2307/1520956.

US Environmental Protection Agency (USEPA) (1986). Michigan dioxin studies. Dow chemical wastewater characterization study. Tittabawassee River Sediments and Native Fish. EPA-905/4-88-003. Chicago, IL: US Environmental Protection Agency, Region V.

U.S. Environmental Protection Agency (USEPA) (1998). Polychlorinated dibenzodioxins (PCDDs) and polychlorinated dibenzofurnas (PCDFs) by high-resolution gas chromatography/high-resolution mas spectrometry (HRGC/HRMS). Revision 1. Method 8290A. SW846. Washington, DC: US Environmental Protection Agency.

van den Berg, M., Craane, B., Sinnige, T., van Mourik, S., Dirksen, S., Boudewijn, T., et al. (1994). Biochemical and toxic effects of polychlorinated biphenyls (PCBs), dibenzo- $p$-dioxins (PCDDs) and dibenzofurans (PCDFs) in the cormorant (Phalacrocorax carbo) after in ovo exposure. Environmental Toxicology and Chemistry, 13, 803-816. doi:10.1897/1552-8618(1994) 13[803:BATEOP]2.0.CO;2.

van den Berg, M., Birnbaum, L., Bosveld, A., Brunstrom, B., Cook, P., Feeley, P., et al. (1998). Toxic equivalency factors (TEFs) for PCBs, PCDDs, PCDFs for humans and wildlife. Environmental Health Perspectives, 106, 775-792. doi:10.2307/3434121.

Witt, J. W. (2006). Great blue heron productivity at Mason Neck National Wildlife Refuge in northern Virginia, and the potential impacts of weather during a 13-year interval. Waterbirds, 29, 345-349. doi: 10.1675/1524-4695(2006)29[345:GBHPAM]2.0.CO;2. 